Agro-Science Journal of Tropical Agriculture, Food, Environment and Extension Volume 10 Number 2 Mav 2011 pp. 7 - 15

ISSN1119-7455

\title{
COMBINING ABILITY ANALYSIS FOR YIELD AND YIELD COMPONENTS IN EIGHT BREEDING LINES OF RICE (Oryza sativa L.)
}

\author{
Onyia, V. N. \\ Department of Crop Science, University of Nigeria, Nsukka, Nigeria.
}

\begin{abstract}
Twenty-eight hybrids produced from diallel crossing excluding reciprocals among eight parents were studied along with the parents for combining ability for yield and 12 yield components. The study revealed the importance of both additive and non-additive gene effects in governing yield and most of the yield components with preponderance of non-additive gene action for most of the yield components. The analysis of variance for combining ability indicated that mean square due to general combining ability (GCA) was significant for all the characters except for number of tillers/ ${ }^{2}$, panicle length (cm), number of spikelets /panicle, number of fertile spikelets / panicle, 1000 - grain weight(g) and grain yield(tha $\left.{ }^{-1}\right)$ which was non significant. Mean square due to specific combining ability (SCA) were significant for all the characters except for spikelets/panicle, fertile spikelets/panicle, 1000-grain weight(g) and grain yield(tha $\left.{ }^{-1}\right)$ which were non significant. This suggests the importance of both additive and non-additive gene effects in the materials under study. The parent WAB 450-I-B-163-41 was found to be a good general combiner. The hybrids WAB 56-144-FX $x$ WAB 56-100, WAB 450-1-B-163-41 x IRAT 317, WAB 450-1-B163-41 x IR 47-701-63-1, WAB 450-1-B-163-41 $x$ IRAT 239,WAB 35-1-FX $x$ WAB 56 -100, WAB 35 -1-FX $x$ WAB 56100, IRAT $239 x$ WAB $56-100$ and IRAT $317 x$ IRAT 239 have shown significant favorable (SCA) effect for yield and different yield components. Since non- additive/dominance components were higher than the additive components for all the characters in both $F_{1}$ and $F_{2}$ generations, bi parental mating and/or reciprocal recurrent selection could be used for genetic improvement of these characters.
\end{abstract}

Keywords: Diallel analysis, combining ability, additive and non additive gene effects, GCA effect, SCA effect.

\section{INTRODUCTION}

The cultivated rice (Oryza sativa $\mathrm{L}$. $2 \mathrm{n}=24$ ) belongs to the tribe Oryza under the sub family, Pooideae in the grass family, Poaceae (Gramineae). Oryza species have already been attracting enormous attention from scientists world wide because of their economic importance. Many studies on taxonomy, phylogeny and genetic relationships of the Oryza species have been conducted (Chang, 1985, Morishinma et al., 1992, Wang et al., 1992, Lu et al., 1998).

Rice has been cultivated in south eastern Asia since ancient times where it is one of the oldest of food crops, but is now grown in all regions of the world where conditions are suitable for its cultivation (Purseglove, 1975). In Nigeria, the demand for rice is increasingly higher than its production due to taste and rapid population growth. In 1981, the
International Rice Research Institute (IRRI) reported that due to increase urbanization and ease of cooking and storage, rice is progressively replacing other cereals and traditional food crops in West Africa. It stressed further that most African countries are increasingly resorting to importation which became costlier due to trade imbalance.

The development of a new variety with high yield and resistance to pest and diseases is the unique target of all rice breeders. An understanding of the inheritance pattern of the traits in the rice crop is necessary in organizing a good breeding programme for the crop. In the study of quantitative genetics, the breeder uses the observations made on the population to predict the outcome of any particular breeding method. The breeders also, determine how these observable properties are being influenced by the properties of the genes concerned and by various non-genetic 
circumstances. The first step in a successful breeding program is to select appropriate parents. Diallel analysis provides a systematic approach for the detection of appropriate parents and crosses superior in terms of the investigated characters. The method also helps plant breeders to choose the most efficient selection method by allowing them to estimate several genetic parameters.

The diallel crossing method in rice is used principally to determine the general and specific combining abilities of the quantitative properties (Chan et al; 1990, Hoang and Tran, 1991). Combining ability describes the breeding value of parental lines to produce hybrids. Sprague and Tatum (1942) used the term general combining ability (GCA) to designate the average performance of a line in hybrid combinations, and used the term specific combining ability (SCA) to define those cases in which certain combinations do relatively better or worse than expected on the basis of the average performance of the lines involved. The purpose of this research was to estimate the GCA and SCA effects for yield and yield components among Eight (8) breeding lines of rice and to determine appropriate parents and crosses for the investigated traits.

\section{MATERIALS AND METHODS}

All possible cross combinations excluding reciprocals were made among eight upland rice breeding lines: WAB 450-1-B-16314, IRAT 317, WAB 35-1-FX, IR-701-6-3-1, WAB 35-2-FX, WAB 56-144-FX, IRAT 239 and WAB 56-100 obtained from the National Cereals Research Institute (NCRI) Baddeggi, Niger State between 2002 and 2006 at the experimental field of the NCRI Amakanma Sub-station, Umuahia, Abia State Nigeria. Amakanma is located at Latitude $5^{0} 24^{\prime}-5^{0} .30$ ' and Longitude $7^{0} 31^{\prime}-7^{0} 37^{\prime} \mathrm{E}$. The vegetation and climate are typical of the degraded humid forest of South - East agro ecological zone of Nigeria. The soil is classified as Ultisol.

The parental lines were grown in the field and crosses were made in all possible combinations. The $\mathrm{F}_{1}$ hybrids and their respective parents were planted out in the field in a randomized complete block design with four replicates. The seed and pollen parents of each of the hybrids were grown beside their respective offspring. This was done to ease comparisons. The rice plants were spaced $25 \mathrm{~cm} \times 25 \mathrm{~cm}$ apart.

Routine field management practices were carried out as at when due. The rice plots were weeded twenty one (21) and forty two (42) days after planting (DAP), respectively. Both weedings were done with the aid of a hoe. Bush clearing around the rice plots to check rodent attack was carried out. Compound fertilizer (N.P.K $20: 10: 10$ ) were applied at the rate of $60 \mathrm{~kg} \mathrm{~N}, 30 \mathrm{~kg} \mathrm{P}$ and $30 \mathrm{~kg} \mathrm{~K}$ per hectare after the first weeding in each of the experiment. At the onset of booting, the rice plants were top dressed with urea at the rate of $30 \mathrm{~kg} / \mathrm{ha}$. The fertilizer was applied manually between the rows of rice seedlings.. Data were collected from all plants, leaving one border plant on each side of the row (Dhaliwel and Sharma, 1990). Observations were recorded on 12 characters namely; number of days to $50 \%$ heading, plant height $(\mathrm{cm})$, at maturity, number of tillers/plant, number of tillers $/ \mathrm{m}^{2}$, number of panicles/hill, number of panicles $/ \mathrm{m}^{2}$, panicle length $(\mathrm{cm})$, number of spikelets/panicle, number of fertile spikelets/panicle, number of days to maturity, 1000-grain weight (g), and grain yield ton $\mathrm{ha}^{-1}$ ).

The data collected were subjected to Analysis of Variance (ANOVA) The essence was to determine the differences and similarities, existing between the parent and the progenies involved in each cross. Later, the statistical procedures of Hayman (1954) for genetic component analysis and Griffing (1956) method 1 , model 2 for combining ability analysis were used.

\section{RESULTS AND DISCUSSION}

The results of the analysis of variance for combining ability presented in Table 1 show that mean square due to general combining ability (GCA) was significant for all the characters under investigation. The results also indicated that mean squares due to specific combining ability (SCA) were significant for all the traits, thus indicating the importance of both additive and non-additive type of gene effects in controlling these traits.

General and specific combining ability effects are important indicators of the potential of parental lines for generating superior breeding populations. A small or negative combining effect indicates a poor ability to transfer its genetic superiority to hybrids (Cruz and Regazzi, 1994). The largest positive values have the largest effects. On the other hand, the largest negative values have the smallest effects (Tenkouano et al., 1998). 
Onyia, V. N.

Table 1. Analysis of variance showing sources of variation, degree of freedom and mean square values for combining ability in $8 \times 8$ half diallel analysis using Griffing's method 1 model 2.

\begin{tabular}{|c|c|c|c|c|c|c|c|c|c|c|c|c|c|}
\hline $\begin{array}{l}\text { Source of } \\
\text { variation }\end{array}$ & D.f & $\begin{array}{l}\text { Days to } \\
50 \% \\
\text { flowering }\end{array}$ & $\begin{array}{l}\text { Plant } \\
\text { height } \\
(\mathrm{cm})\end{array}$ & $\begin{array}{l}\text { Number of } \\
\text { Tillers/plant }\end{array}$ & $\begin{array}{l}\text { Number of } \\
\text { Tillers } / \mathrm{m}^{2}\end{array}$ & $\begin{array}{l}\text { Number } \\
\text { of } \\
\text { panicle/ } \\
\text { hill } \\
\end{array}$ & $\begin{array}{l}\begin{array}{l}\text { Number } \\
\text { of } \\
\text { panicle/ } \\
\mathbf{m}^{2}\end{array} \\
\end{array}$ & $\begin{array}{l}\text { Panicle } \\
\text { length } \\
(\mathrm{cm})\end{array}$ & $\begin{array}{l}\begin{array}{l}\text { Number } \\
\text { of } \\
\text { spikelet/ }\end{array} \\
\text { Panicle } \\
\end{array}$ & $\begin{array}{l}\begin{array}{l}\text { Number } \\
\text { of fertile } \\
\text { spikelet/ } \\
\text { panicle }\end{array} \\
\end{array}$ & $\begin{array}{l}\text { Number } \\
\text { of days to } \\
\text { maturity }\end{array}$ & $\begin{array}{l}\text { 1000-grain } \\
\text { weight } \\
\text { (g) }\end{array}$ & $\begin{array}{l}\text { Grain } \\
\left(\text { tha }^{-1}\right)\end{array}$ \\
\hline GCA & 7 & $176.178^{* *}$ & $930.328^{*}$ & $4.11^{*}$ & $1969.9^{*}$ & $4.41^{*}$ & $1909.3^{* * *}$ & $11.01^{*}$ & $15168.4^{*}$ & $9620.68^{*}$ & $176.17^{* *}$ & $115.40^{*}$ & $2.171^{*}$ \\
\hline Error & 105 & 0.53 & 463.52 & 0.32 & 10.94 & 0.48 & 34.62 & 12.03 & 12.51 & 2.94 & 6.20 & 0.3927 & 0.184 \\
\hline GCA/SCA & & 15.716 & 48.708 & 3.211 & 10.186 & 29.40 & 23.52 & 3.67 & 47.847 & 48.190 & 15.715 & 15.679 & 33.40 \\
\hline
\end{tabular}

** Significant at $1 \%$ level , *Significant at $5 \%$ level., of probability

Table 2: General combining ability effects and mean performance (in parenthesis) of 8 parents from a $8 \times 8$ half diallel analysis using Griffin's method 1 model 2.

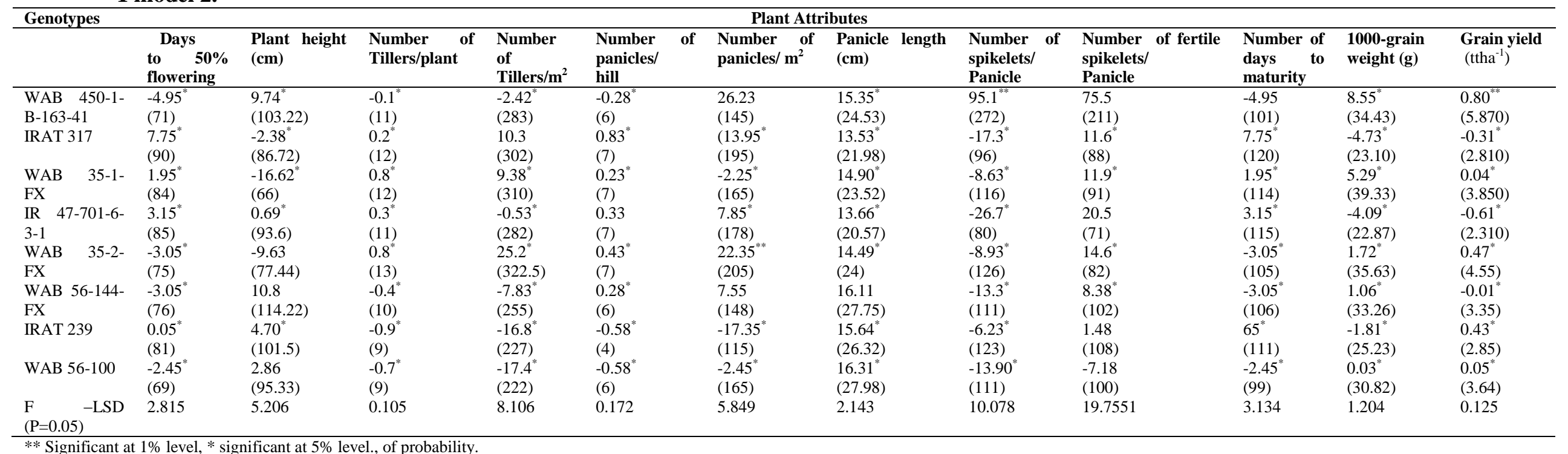

** Significant at $1 \%$ level, * significant at $5 \%$ level., of probability. 
Table 3: Specific combining ability effects and mean performance of early $x$ early hybrids (in parenthesis) from a 8x8 dallel analysis using Griffin's method 1 model 2.

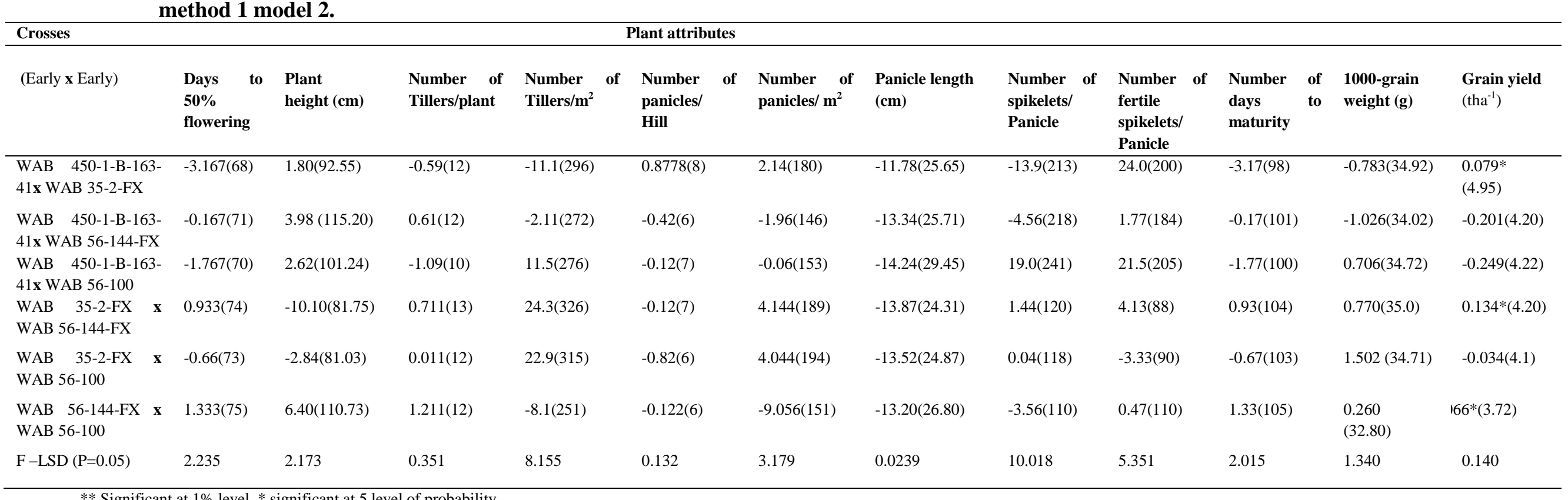

** Significant at $1 \%$ level, * significant at 5 level of probability 
A high positive GCA value means the parental line has high potential for generating superior offspring (Cruz and Regazzi, 1994). Significant GCA effects were found among most of the parents for the different characteristics estimated.

The genotype, WAB 450-1-B-163-41 was found to be a good general combiner for grain yield and important yield components like number of days to 50 per cent flowering (earliness), number of days to maturity (duration), number of panicles $/ \mathrm{m}^{2}$, number of spikelets/panicle, number of fertile spikelets/panicle and 1000 grain weight (Table 2). Apart from WAB 450-1-B-163-41, good general combiners for different characters are IRAT 317 for short height and number of panicles/hill, IR 47-701-6-3-1 for number of tillers/plant, number of panicles/hill, number of panicles $/ \mathrm{m}^{2}$ and number of fertile spilelets/panicle and WAB 35-2-Fx for number of days to $50 \%$ flowering (earliness), number of days to maturity (duration), number of panicles $/ \mathrm{m}^{2}$, number of fertile spikelets/panicle, 1000 -grain weight and grain yield. Significant

SCA effects were found for most of the hybrids. Six hybrids namely WAB 450-1-B-163-41 x WAB 35-2-FX, WAB 35-2-FX x WAB 56-144FX, WAB 56-144-FX x WAB 56-100 ( Table 3), IRAT $317 \mathbf{x}$ WAB 56-100 ( Table 5), IRAT 317 x IRAT 239, and IR 47-70-6-3-1 x IRAT 239 (Table 6) exhibited significant SCA effects for grain yield (Table 3). Among these hybrids, three have at least one parent WAB 35-2-FX, IRAT 239 and WAB 56-100 with positive GCA effect. The hybrid WAB 450-1-B-163-41x IRAT 239 showed significant favorable SCA effect for six yield components (Table 4); the hybrid, WAB 35-2- FX x WAB 56-144-FX for five yield components (Table 3 ) and the hybrid IR 47-701-6-3-1 x WAB 35-2-FX for four yield components (Table 5). In these hybrids all kinds of parental combinations like high $\mathrm{x}$ high, high $\mathrm{x}$ low, medium $\mathrm{x}$ medium and medium $\mathrm{x}$ low were found. This suggests that either additive $x$ additive and/or additive $\mathrm{x}$ dominance genetic interactions were predominant. The superiority of these crosses may be due to complementary and duplicate type gene interactions. Similar results were reported by Vanaja et al., (2003), Katre and Jambhale (1996) and Ramalingam et al., (1997). Peng and Virmani (1990) had earlier reported about the possibility of interaction between positive alleles from good combiners and negative alleles from poor combiners in high $\mathrm{x}$-low combining cross and suggested for the exploration of heterosis in $\mathrm{F}_{1}$ as their high yield potential would be unfixable in succeeding generations. Crosses involving dominant $\mathrm{X}$ recessive gene interaction might tend to be nonfixable.

The results obtained is in line with the findings of $\mathrm{Yu}$ et al. (2002) who demonstrated the importance of epistatic interactions in the genetic bases of heading date and plant height by using Map marker/Quantitative trait loci (QTLs) and that of Verma and Srivastara (2004) who found that GCA and SCA effects were highly significant for number of days to $50 \%$ flowering, plant height, number of productive tillers, panicle length, number of spikelets/panicle and 1000-grain weight indicating the relevance of both additive and non additive effects in the inheritance of these traits as well as the greater importance of non-aditive gene action. 
Table 4: Specific combining ability effects and mean performance of early $x$ medium hybrids (in parenthesis) from a $8 \times 8$ dallel analysis using Griffin's method 1 model 2.

\begin{tabular}{|c|c|c|c|c|c|c|c|c|c|c|c|c|}
\hline \multicolumn{5}{|l|}{ Crosses } & \multicolumn{8}{|c|}{ Plant Attributes } \\
\hline (Early x Medium) & $\begin{array}{l}\text { Days to } \mathbf{5 0 \%} \\
\text { flowering }\end{array}$ & $\begin{array}{l}\text { Plant height } \\
\text { (cm) }\end{array}$ & $\begin{array}{l}\text { Number of } \\
\text { Tillers/plant }\end{array}$ & $\begin{array}{l}\text { Number of } \\
\text { Tillers } / \mathrm{m}^{2}\end{array}$ & $\begin{array}{l}\text { Number of } \\
\text { panicles/ } \\
\text { Hill }\end{array}$ & $\begin{array}{l}\text { Number of } \\
\text { panicles/ } \mathbf{m}^{2}\end{array}$ & $\begin{array}{l}\text { Panicle } \\
\text { length } \\
(\mathrm{cm})\end{array}$ & $\begin{array}{l}\text { Number of } \\
\text { spikelets/ } \\
\text { panicle }\end{array}$ & $\begin{array}{l}\text { Number } \\
\text { of } \\
\text { fertile } \\
\text { spikelets/ } \\
\text { panicle }\end{array}$ & $\begin{array}{l}\text { Number } \\
\text { of } \\
\text { days to } \\
\text { maturity }\end{array}$ & $\begin{array}{l}\text { 1000- } \\
\text { grain } \\
\text { weight (g) }\end{array}$ & $\begin{array}{l}\text { Grain } \\
\text { yield } \\
\left(\text { tha }^{-1}\right)\end{array}$ \\
\hline WAB $\quad 450-1-B-163-$ & 0.03 & -2.299 & 0.011 & -7.21 & 0.478 & -7.456 & -12.96 & 42.4 & 20.9 & 0.03 & 3.07 & -0.262 \\
\hline 41x IRAT 317 & (81) & (98.70) & (12) & (285) & (8) & (162) & (23) & (261) & (200) & (112) & $(35.33)$ & (3.84) \\
\hline WAB 450-1-B-163-41 & -2.567 & 4.9024 & 1.411 & -11.3 & 0.0778 & 1.74 & $(-13)$ & 34.7 & 11.3 & -1.96 & -3.262 & -0.307 \\
\hline x WAB 35-1-FX & (74) & (88.67) & (14) & (280) & (7) & (155) & & (262) & (190) & (104) & $(36.01)$ & (4.15) \\
\hline WAB 450-1-B-163- & 0.633 & -1.267 & 0.911 & -3.41 & -0.022 & -5.356 & -12.29 & 15.8 & 9.86 & 0.63 & 2.419 & -0.187 \\
\hline 41x IR 47-701-6-3-1 & (78) & (99.8) & (13) & (278) & (7) & (158) & (23.67) & (225) & (180) & (108) & $(32.31)$ & $(3.62)$ \\
\hline WAB 450-1-B-163- & 3.133 & 3.846 & 0.111 & 16.8 & -0.122 & 2.844 & -13.57 & 24.3 & 20.9 & 3.13 & 3.031 & 0.181 \\
\hline 41x IRAT 239 & (78) & (108.93) & (11) & (282) & (6) & (141) & $(25.01)$ & (254) & (180) & (108) & $(35.21)$ & $(3.80)$ \\
\hline WAB $\quad 35-2-F X \quad \mathbf{x}$ & -5.767 & -5.821 & 0.211 & 19.2 & 1.178 & 25.944 & -12.90 & 1.34 & -2.03 & -5.76 & 3.237 & -0.196 \\
\hline IRAT 239 & (71) & (79.90) & (12) & (312) & (8) & (201) & $(24.82)$ & (127) & (97) & (101) & $(34.61)$ & (3.45) \\
\hline WAB $56-144-F X \quad \mathbf{x}$ & -5.767 & 10.037 & 1.411 & -9.71 & -1.122 & 6.844 & -12.23 & 0.74 & 0.77 & -5.77 & 2.335 & -0.106 \\
\hline IRAT 239 & (71) & (116.22) & (12) & (250) & (5) & (152) & (27.11) & (122) & (106) & (101) & $(33.05)$ & $(3.00)$ \\
\hline $\mathrm{F}-\mathrm{LSD}(\mathrm{P}=0.05)$ & 1.623 & 4.160 & 0.201 & 7.145 & 2.150 & 4.539 & 9.211 & 6.391 & 2.440 & 2.150 & 0.112 & 0.180 \\
\hline
\end{tabular}

** Significant at $1 \%$ level, * significant at 5 level of probability. 
Onyia, V. N.

Table 5: Specific combining ability effects and mean performance of medium $x$ early of hybrids (in parenthesis) from a $8 \times 8$ dallel analysis using Griffin's method 1 model 2.

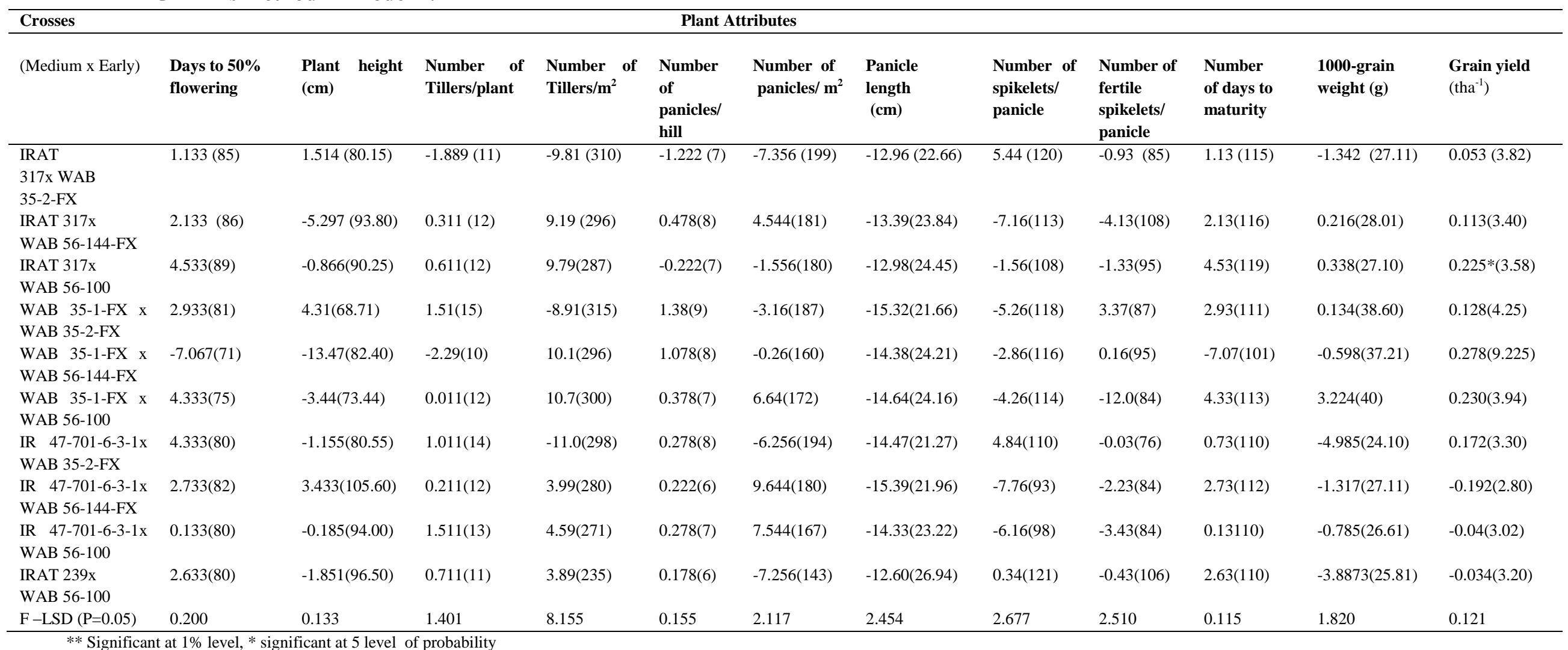


Table 6: Specific combining ability effects and mean performance of medium $\mathbf{x}$ medium hybrids (in parenthesis) from a 8x8 dallel analysis using Griffin's method 1 model 2.

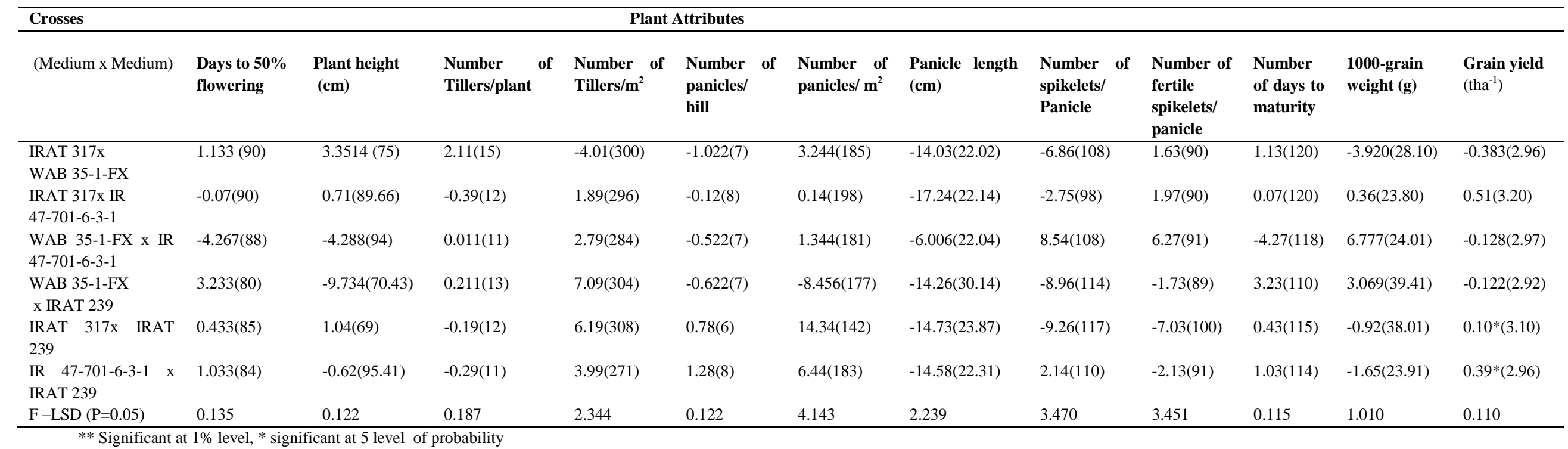




\section{CONCLUSION}

The diallel analysis study showed that much of the genetic variation of each of the traits was due to additive gene effect. Genetic component and combining ability analyses also revealed significant contribution of both fixable and non-fixable gene effects with preponderance of the later in the inheritance of various physiological traits studied. The different measures of the relative values of additive and non-additive gene effects showed that the dominant gene effects made the major contributions in most of the traits in all the crosses. Additive gene effects had the lowest magnitude in all the attributes measured, an indication that this type of gene effect is not important in the explanation of variation in these attributes although it was significant in most of the attributes. WAB 450-1-B-163-41, IRAT 317, IR 47-701-6-3-1 and WAB 35-2-FX were observed to be good general combiners and these parents may be utilized in yield improvement along with physiological traits in targeted ecosystems. Hybrids WAB 4501-B-163-41x WAB 35-2-FX, WAB 35-2-FX x WAB 56-144FX, WAB 56-144-FX $\mathbf{x}$ WAB 56-100, IRAT $317 \mathbf{x}$ IRAT 239 and IR 47-701-6-3-1 x IRAT 239 could be utilized for hybrid rice programme and for selecting out favorable segregants from segregating generations.

\section{REFERENCES}

Chang, T.T (1985), Crop history and genetic conservation: Rice, a case study of Iowa State J. Res. 59; 425 - 455.

Chan, D.L., Hoang V.F.. Chan,V.Z. , Fam D.K.H., Lee T.C. and Ngugen M.F. (1990). Using the method of diallel crossing to evaluate the combining ability of some rice cultivars. Doklady Vsesoyuznol Akademii Selskohozy aist venuykh Nauk 4: 16-20.

Cruz, C.D and Regazzi A.J. (1994). Modelos biotricos aplicados aomehoraments genetico Universidade Federal de Vicos, imprensa universitaria, Vocosa, Minas gerais, Brazil.

Dhalwal, T.S and Sharma H.L. 1990. Combining ability and maternal effects for agronomic and grain charaters in rice Oryza 27: 122-128.

Griffing, B. (1956). Concept of general and specific combining ability in relation to diallel crossing system Aust J.Biol Sci 9: 463-493.

Hayman, B.I. (1954). The theory and analysis of diallel crosses. Genetics, 39: 789-809.

Hoang, V.P and Tran D.L. (1991). Estimates of Combining ability of some rice varieties in a diaollel crossing system Int. rice, res. News 1: 16-(3). 9.

Katre, N. B and Jambhale N.D. (1996). Combining ability for grain yield and related character in rice Oryza 33: 21 25.

Lu, B.R., Navedo., M.E.B, Juliano, A.B and Jackson, M.T. (1998). Taxonomic status of Oryza glumaepatula Stend III. Assessment of genetic affinity among A. A Genome species from the new world. Asia and Australia. Genet. Resour crop evol. 45: 205 - 214.

Morishinma, H., Sano, Y and Oka, H. I (1992) Evolutionary studies in cultivated rice and it's wild relative. Oxford Surv. Evol. Biol 8: 135 - 184.

Peng, J.Y and Vir mani S.S. (1990). Combinig ability for yield and four yield related traits in relation to breeding in rice Oryza, 27: 1-10.

Purseglove, J.N. (1975) Tropical crops Monocotyledons. Longman Group. 162pp.

Ramalingam Nadarajan, J., N. Vanniarajan K. and Rangasamy P. 1997. Combining ability studies involving CMS lines in rice Oryza 34: 4-7.

Sprague, G.E and Taturn L.A. (1942). General versus specific combining ability in single crosses of corn. J. Am Soc Agron. 34: 923-932.

Tenkouano, A., Ortiz R. and Vuylstece D. 1998. Combining ability for yield and plant phenology in plantain-derived Populations. Euphytica 104, 151-158.

Vanaja, T., Luckins, C. Babu,V. Radhakrishnan V. and Pushkaran K. (2003). Combining ability analysis for yield and yield components in rice varieties of diverse origin. Journal of Tropical Agriculture 41: 7-15.

Verma, O. P and Srivastara H.K. (2004). Genetic component and combining ability analysis in relation to heterosis for yield and associated traits using three diverse rice growing ecosystems. Field Crops Res. 88: 91-100.

Wang, Z.Y., Second, G. and Tanksler, S.D (1992) Polymorphism and phylogenetic relationship among spps in the genus Oryza as determined by analysis of nuclear RFLPs. Theor. Appl Genet 83: $565-58.1$

Yu, S.B.,.L. J.X, XU C. G. and Li V. H. (2002). Identification of quantitative trait loci interactions for plant height and heeding date in rice. Theor. Appl. Genet. 104: 69-625. 